\title{
Discontinuation of antimicrobials and costs of treating patients with infection*
}

\author{
Descalonamento de antimicrobiano e custos do tratamento de pacientes com infeç̧ão \\ Descalonamento antimicrobiano y costos con el tratamiento de pacientes con infecciones
}

Adriana Cristina de Oliveira ${ }^{1}$, Adriana Oliveira de Paula ${ }^{2}$

\begin{abstract}
Objective: To evaluate the repercussions of discontinuation the cost with the antimicrobial treatment of patients with bloodstream infection. Methods: A historical cohort study conducted in the intensive care unit of a hospital in Belo Horizonte (MG). The population included 62 patients with bloodstream infection caused by Staphylococcus aureus. Data were collected between March/2007 and March/2011 from patients' medical records, Commission of Hospital Infection Control and Sector of Costs, with descriptive and univariate analysis. Results: Colonization was associated with the occurrence of infection with resistant microorganisms $(p<0.05)$. The antimicrobial discontinuation reduced the spectrum of action of the antibiotic prescribed, and the treatment costs $(\mathrm{R} \$ 2,673.12$ to $\mathrm{R} \$ 727.03, \mathrm{p}=0.001)$. Conclusion: The discontinuation of antimicrobials favored the redirection of patient therapy, reducing, where necessary, the spectrum of action of the prescribed antimicrobial and, consequently, the costs of treatment.Keywords: Drug resistance; Drug costs; Bacterial infections
\end{abstract}

\section{RESUMO}

Objetivo: Avaliar as repercussões do descalonamento nos custos com o tratamento antimicrobiano de pacientes com infecção da corrente sanguínea. Métodos: Estudo de coorte histórica realizado em Unidade de Terapia Intensiva de hospital de Belo Horizonte (MG). A população incluiu 62 pacientes com infecção da corrente sanguínea causada por Staphylococcus aureus. Os dados foram coletados entre março/2007 e março/2011 nos prontuários dos pacientes, Comissão de Controle de Infecção Hospitalar e Setor de Custos com análise, descritiva e univariada. Resultados: A colonização esteve associada à ocorrência de infecção por micro-organismo resistente $(\mathrm{p}<0.05)$. O descalonamento antimicrobiano reduziu o espectro de ação do antibiótico prescrito e os custos com o tratamento (de $R \$ 2.673,12$ para $R \$ 727,03$, $p=0,001$ ). Conclusão: O descalonamento de antimicrobianos favoreceu o redirecionamento da terapia do paciente, reduzindo, quando necessário, o espectro de ação do antimicrobiano prescrito e, consequentemente, os custos com o tratamento.

Descritores: Resistência a medicamentos; Custos de medicamentos; Infecções bacterianas

\section{RESUMEN}

Objetivo: Evaluar las repercusiones del desescalamiento en los costos con el tratamiento antimicrobiano de pacientes con infección de la corriente sanguínea. Métodos: Estudio de cohorte histórica realizado en una Unidad de Terapia Intensiva de un hospital de Belo Horizonte (MG). La población incluyó a 62 pacientes con infección de la corriente sanguínea causada por Staphylococcus aureus. Los datos fueron recolectados entre marzo/2007 y marzo/2011 en las historias clínicas de los pacientes, Comisión de Control de Infección Hospitalaria y Sector de Costos con análisis, descriptivo y univariado. Resultados: La colonización estuvo asociada a la ocurrencia de infección por microorganismo resistente $(\mathrm{p}<0.05)$. El desescalamiento antimicrobiano redujo el espectro de acción del antibiótico prescrito y los costos con el tratamiento (de $\mathrm{R} \$ 2.673,12$ para $\mathrm{R} \$ 727,03, \mathrm{p}=0,001$ ). Conclusión: El desescalamiento de antimicrobianos favoreció el redireccionamiento de la terapia del paciente, reduciendo, cuando necesario, el espectro de acción del antimicrobiano prescrito y, consecuentemente, los costos con el tratamiento. Descriptores: Resistencia a medicamentos; Costos en drogas; Infecciones bacterianas

\footnotetext{
* Study extracted from Master's dissertation entitled "Costs with antimicrobials treatment in patients with bloodstream infection in an Intensive Care Unit" - presented at School of Nursing, Federal University of Minas Gerais - UFMG - Belo Horizonte (MG), Brazil.

1 Associate Professor, Department of Basic Nursing of School of Nursing, Federal University of Minas Gerais - UFMG - Belo Horizonte (MG), Brazil.

${ }^{2}$ PhD student in Nursing - Graduation Program of School of Nursing, Federal University of Minas Gerais - UFMG - Belo Horizonte (MG), Brazil. Capes Scholarship.
} 


\section{INTRODUCTION}

The indiscriminate use of antibiotics has been described as a predisposing factor for the occurrence of bacterial resistance since the 1950s, after the discovery and the availability of penicillin for the treatment of infections, the first cases of Staphylococcus aureus resistance were reported in the United States of America ${ }^{(1,2)}$.

On the world scenario, including Brazil, the emergence of strain of antimicrobial resistant such as Klebsiella pneumoniae carbapenemase-producer (KPC) or Staphylococcus aureus with resistance to Vancomycin-Intermediate (VISA), have brought additional concerns given the complexity of an effective treatment, due to the reduction of therapeutics options and the need for empirical associations ${ }^{(3,4)}$.

Given this situation, initiatives of the Brazilian government, such as Resolution No. 44 of October 26, 2010, preconized the sale of antimicrobials only with a physician prescription and its retention, in order to have better control with respect to the marketing and consumption of these drugs, and thus contribute to the reduction of bacterial resistance. The fact shows how this issue begins to be treated more seriously in the country, highlighting the need to use antibiotics (ATB) in a rational manner to ensure the prevention of the spread of resistant microorganisms ${ }^{(5)}$.

Nevertheless, in the hospital environment, specifically in the Intensive Care Units (ICU), the occurrence of Healthcare Associated Infections (HCAI) due to microorganisms resistance has become increasingly common ${ }^{(6,7)}$.

Based on this fact and on the premise that receiving appropriate treatment within 24 hours after the diagnosis of HCAI is fundamental to a more favorable outcome for the patient, it is observed an increasing use of broad-spectrum antibiotics action in the empirical treatment (one that occurs before microbiological confirmation of the infection causative agent and resistance profile ${ }^{(8,9)}$.

This practice has been endorsed by the main agencies and international and national health societies, aiming to try to reduce patient complications and consequently mortality rates ${ }^{(8-12)}$. However, due to the possibility of selecting resistant bacteria to broad-spectrum ATB used in the empirical treatment, some strategies have been used in order to ease the consequences of the action use of broad-spectrum antibiotics. Among them, one can cite the de-escalation, ie adjusting for the most appropriate antibiotic once the culture results is available, the audit of antimicrobials, as well as the restriction of some drugs, with its use released only after prior approval of the medical auditors of the Hospital Infection Control Committee (HICC) ${ }^{(9)}$.
De-escalation is highlighted among the above measures, particularly by allowing the adequacy of drugs prescription, according to the causative agent of infection, promoting the rational use of ATB and thereby minimizing the selection of multiresistant bacteria. Still, some studies report that this can reduce costs with antimicrobial treatment. However, there are few researches in national and international literature reflecting on this subject ${ }^{(13)}$. With this framework, it is important to question whether de-escalation presents impacts on costs of antimicrobial treatment of patients with infection.

In this regard, given the relevance of this topic, this study aimed to evaluate the impact of de-escalation costs of antimicrobial treatment in patients with bloodstream infection caused by Staphylococcus aureus resistant or sensitive to oxacillin (MRSA or MSSA, respectively).

\section{METHODS}

This is a retrospective epidemiological study, historical cohort type, conducted in an Intensive Care Unit of a private and large scale hospital, located in the city of Belo Horizonte (MG).

The study population consisted of all patients who received a diagnosis of bloodstream infection (BSI) due to Staphylococcus aureus, during the period between March 2007 and March 2011, according to the criteria established by the National Healthcare Safety Network (Signs and Symptoms + laboratory results). It was considered also the confirmation of the microorganism causing the BSI and resistance profile for these patients who completed treatment with antibiotics during hospitalization. We excluded patients with bloodstream infections caused by microorganisms simultaneously sensitive and resistant. To preserve the assumption of independence of observations, only the first bloodstream infection treated appropriately for each patient was included in the study. The group of patients infected with Staphylococcus aureus resistant to oxacillin was compared to the group of patients with infections caused by Staphylococcus aureus sensitive to oxacillin.

Data collection was performed by the researcher, using a structured instrument, which contained information on the occurrence of BSI and the number of doses used in antimicrobial treatment. This information was obtained through records on patients' charts and HICC, respectively. Those relating to the costs of antimicrobials were researched through the annual value of each dose of antibiotic, in Reais (Brazilian currency), and subsequently converted into U.S. dollars, in order to allow future comparisons by standardizing the currency. The dollar conversion was performed according to the 
Federal Reserve Statistical Release of the United States, based on annual exchange rates, launching between the years 2007- 2011 ${ }^{(14)}$.

We identified 78 patients diagnosed with bloodstream infection associated with Staphylococcus aureus between March 2007 and March 2011. Of these, eight were excluded due to infections related to resistant and sensitive microorganisms concurrently and eight others have died before completing treatment. From the remaining 62 patients, 31 were included in the group of patients with resistant microorganisms and 31 in the group of patients with sensitive microorganisms.

The data were analyzed with SPSS (19.0). We performed a descriptive analysis presenting median values and interquartile range $(25 \%$ percentile value $-75 \%$ percentile value) for continuous variables, the absolute and percentage value for categorical variables. Subse- quently, to identify differences between the variables related to the occurrence of infection by microorganisms resistant (MR) or microorganisms sensitive (MS) the chi-square or Fisher exact test were performed in case of categorical variables, and Mann -Whitney test in case of continuous variables.

The research project was approved by the Institutional Ethics Committee and the provisions of Resolution No. 196/96 were respected, in relation to research with humans (ETIC No: 658/2011).

\section{RESULTS}

Data in Table 1 show the clinical and epidemiological characteristics of patients, according to the resistance profile of the causative agent of bloodstream infection (Staphylococcus aureus sensitive or resistant to oxacillin).

Table 1. Clinical and epidemiological characteristics of patients, according to the sensitivity profile of the causative agent of bloodstream infection (MRSA or MSSA). Belo Horizonte-MG, 2011

\begin{tabular}{|c|c|c|c|}
\hline Variables & $\begin{array}{l}\text { MRSA } \\
(n=31)\end{array}$ & $\begin{array}{c}\text { MSSA } \\
(\mathrm{n}=31)\end{array}$ & p-value \\
\hline \multicolumn{4}{|l|}{ Gender* } \\
\hline Female & 48.4 & 38.7 & \\
\hline Male & 51.6 & 61.3 & 0.442 \\
\hline Age (years) median & $76(53-86)$ & $72(56-81)$ & 0.540 \\
\hline \multicolumn{4}{|l|}{ Hospitalization diagnostic* } \\
\hline Disease of circulatory system & 35.5 & 35.5 & 1.000 \\
\hline Disease of respiratory system & 29.0 & 25.8 & 0.776 \\
\hline Disease of digestive system & 12.9 & 16.1 & 0.718 \\
\hline Infecctious diseases & 9.7 & 3.2 & 0.612 \\
\hline External causes & 3.2 & 16.1 & 0.195 \\
\hline Others & 25.8 & 9.7 & 0.096 \\
\hline \multicolumn{4}{|l|}{ Clinical severity } \\
\hline APACHE II & $15(12-24)$ & $15(11-28)$ & 0.617 \\
\hline \multicolumn{4}{|l|}{ Patient type* } \\
\hline Clinic & 71 & 71 & \\
\hline Surgical & 29 & 29 & 1.000 \\
\hline \multicolumn{4}{|l|}{ Invasive procedures* } \\
\hline Mechanical ventilation & 87.1 & 93.5 & 0.671 \\
\hline Central venous catheter & 90.3 & 87.1 & 1.000 \\
\hline Dwelling vesical catheter removal & 90.3 & 87.1 & 1.000 \\
\hline Intraarterial catheters & 90.3 & 83.9 & 0.707 \\
\hline Colonization by resistant microorganism* & 80.6 & 45.2 & 0.004 \\
\hline Enterococcus sp & 3.2 & 3.2 & 1.000 \\
\hline Staphylococcus aureus & 54.8 & 16.1 & 0.001 \\
\hline Klebsiella pneumoniae & 25.8 & 22.6 & 0.767 \\
\hline Acinetobacter baumanii & 58.1 & 32.3 & 0.041 \\
\hline Pseudomonas aeruginosa & 32.3 & 16.1 & 0.138 \\
\hline Enterobacter sp. & 38.7 & 6.5 & 0.002 \\
\hline \multicolumn{4}{|l|}{ Length of stay } \\
\hline Hospital (days) & $88(33-116)$ & $51(21-94)$ & 0.118 \\
\hline ICU (days) & $33(18-70)$ & $35(13-57)$ & 0.307 \\
\hline \multicolumn{4}{|l|}{ Outcome* } \\
\hline Mortality & 67.7 & 51.6 & 0.196 \\
\hline Hospital discharge & 32.3 & 48.4 & 0.196 \\
\hline
\end{tabular}

* Values expressed in percentage 
Among the factors associated with the occurrence of BSI by MRSA, the colonization by resistant microorganisms was highlighted ( $\mathrm{p}<0.05$ ).

Regarding antimicrobial treatment for BSI, it is noteworthy that, in the institution of the study, there is a standardization of procedures. For the long length of stay in the ICU and high rates of bacterial resistance, the option to start empirical treatment with broad-spectrum antimicrobial (vancomycin, polymyxin B and meropenem or ertapenem), which were adjusted after the culture results (targeted therapy).

Most patients examined received antibiotic empirically $(77.4 \%)$, and the group of patients infected by resistant microorganisms $67.7 \%$ received empirical treatment and the group of patients with sensitive microorganism $87.1 \%(\mathrm{p}=0.068)$. The lack of empirical treatment occurred by absence of diagnosis of infection prior to culture results.

At this stage, the most frequently prescribed antibiotics were vancomycin (69.4\%), polymyxin (46.8\%), ertapenem $(29.0 \%)$, meropenem $(24.2 \%)$, cefepime $(3.2 \%)$, cefotaxime, zosyn, oxacillin and ampicillin $(1.6 \%$ each). It is worth mentioning that there was no significant difference between the groups for any class of antimicrobials prescribed empirically ( $\mathrm{p}>0.05$ ).

After culture results, it is highlighted that $90.3 \%$ of patients received targeted treatment, $93.5 \%$ for patients infected with MRSA and $87.1 \%$ for those with MSSA $(\mathrm{p}=0.671)$. Failure to adjust antimicrobial treatment probably occurred for the delay in culture results, empiric treatment sometimes was already ending or the patient did not present the symptoms of the infection, opting not to perform the targeting.

The most frequently prescribed antibiotics during targeted treatment for both groups were vancomycin $(45.2 \%)$ and oxacillin $(40.3 \%)$ followed by ampicillin (3.2\%), linezolid, teicoplanin, cefotaxime and ciprofloxacin $(1.6 \%$ each).

The data in Table 2 show the distribution percentage of patients according to the use of antibiotics after culture results, grouped according to the classification of the same chemical profile and the sensitivity of the causative agent of BSI (MRSA or MSSA).

It is observed according to the data in Table 2 that, as expected, the group of patients with infection by Staphylococcus aureus resistant to oxacillin used significantly more vancomycin compared to the patients to infection by Staphylococcus aureus sensitive to oxacillin. In contrast, the group (MSSA) received more oxacillin after the culture result compared to the first group (MRSA).
Table 2. Distribution of patients who have received antimicrobials after culture results according to the chemical classification and the sensitivity profile of the causative agent of bloodstream infection (MRSA or MSSA). Belo Horizonte, 2011.

\begin{tabular}{lccc}
\hline Class of antibiotics & $\begin{array}{c}\text { MRSA } \\
(\mathbf{n}=31)\end{array}$ & $\begin{array}{c}\text { MSSA } \\
(\mathbf{n}=31)\end{array}$ & $\begin{array}{c}\text { Valor } \\
\text { de } \mathbf{p}\end{array}$ \\
\hline $\begin{array}{c}\text { Glycopeptides* } \\
\text { Vancomycin }\end{array}$ & 83.9 & 6.5 & $\mathbf{0 . 0 0 0}$ \\
$\quad \begin{array}{c}\text { Teicoplanin } \\
\text { Oxazolidinone* }\end{array}$ & 3.2 & 0.0 & 1.000 \\
$\quad \begin{array}{l}\text { Linezolid } \\
\text { Penicillin* }\end{array}$ & 3.2 & 0.0 & 1.000 \\
$\quad$ Oxacillin & & & \\
$\quad$ Ampicillin & 0 & 80.6 & $\mathbf{0 . 0 0 0}$ \\
Others* & 3.2 & 3.2 & 1.000 \\
$\quad \begin{array}{l}\text { Cefotaxime } \\
\text { Ciprofloxacin }\end{array}$ & 0 & 3.2 & 1.000 \\
\hline
\end{tabular}

* Values expressed in percentages

Regarding the costs for the treatment of patients, Figure 1 shows the costs of empirical antimicrobial treatment, targeted and total.

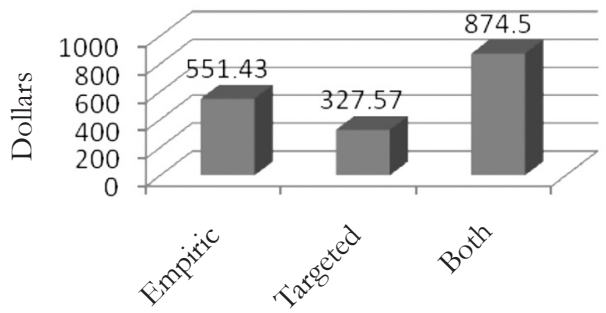

Figure 1. Median costs of antimicrobials treatment per patient, as empirical, targeted or both periods.

As seen in Figure 1, the targeted antibiotic used in treatment, heavily influenced the dropped spending costs on antibiotics $(p=0.000)$. It is noteworthy that, for this analysis, we evaluated only patients who were effectively treated in each period.

Figure 2 shows the differences in the median costs for empirical, targeted and total antimicrobial treatment for each group of patients.

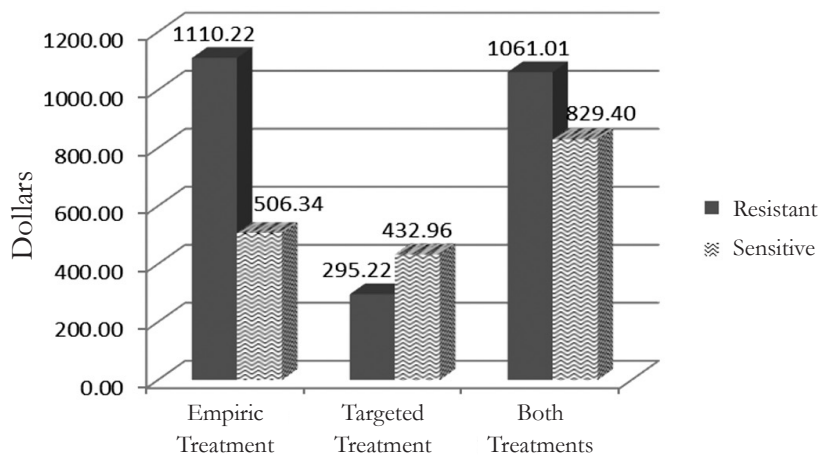

Figure 2. Median cost of antimicrobial treatment according to the length of treatment and the sensitivity profile of the causative agent of BSI (MRSA or MSSA). Belo Horizonte, 2011. 
As seen in Figure 2, there was a difference between spending costs with antimicrobial treatment for patients with resistant and sensitive microorganisms as the result of univariate data presented in Table 3.

Table 3. Median cost of antimicrobial treatment, according to the sensitivity profile of the causative agent of bloodstream infection (MRSA or MSSA). Belo Horizonte, 2011.

\begin{tabular}{|c|c|c|c|}
\hline Variables & MRSA & MSSA & p-value \\
\hline $\begin{array}{l}\text { Empiric } \\
\text { treatment cost }\end{array}$ & $\begin{array}{c}1110.22 \\
(121.73-5315.12)\end{array}$ & $\begin{array}{c}506.34 \\
(50.79-442.80)\end{array}$ & 0.005 \\
\hline $\begin{array}{l}\text { Targeted } \\
\text { treatment cost }\end{array}$ & $\begin{array}{c}304.74 \\
(33.86-2336.99)\end{array}$ & $\begin{array}{c}432.96 \\
(74.08-966.72)\end{array}$ & 0.251 \\
\hline $\begin{array}{l}\text { Total cost of } \\
\text { antimicrobial } \\
\text { treatment }\end{array}$ & $\begin{array}{c}1061.01 \\
(173.90-5937.29)\end{array}$ & $\begin{array}{c}829.40 \\
(195.11-4279.92)\end{array}$ & 0.540 \\
\hline
\end{tabular}

* Value expressed in dollars.

According to Table 3, it is observed that the differences between the costs associated with the antibiotic treatment of patients with resistant and sensitive microorganisms with statistical significance only for the empiric treatment $(p=0.005)$.

\section{DISCUSSION}

With respect to antimicrobial treatment, it is emphasized that the use of broad-spectrum ATB in empirical therapy is associated with lower rates of mortality among critically ill patients ${ }^{(8-9)}$. For this reason, the guidelines for treatment of HCAI recommends that patients who have risk factors for infections caused by resistant microorganisms receive empirical therapy with at least two broad-spectrum antimicrobial ${ }^{(8,10-12)}$.

In the ICU of the selected hospital, the most used antibiotics for the empirical treatment were the broad spectrum (ertapenem, meropenem, polymyxin and vancomycin), independent of the group of patients evaluated (MRSA or MSSA) since the patients risk profile were similar (Table 1). However, it is noteworthy that other strategies were performed to ensure a rational use of antimicrobials. Among them, we can cite the de-escalation, ie the adjustment for the most appropriate antibiotic, as soon as the culture results were available, auditing of antimicrobials, as well as the restriction of some drugs, their use were released only after prior authorization of the HICC medical auditors. Such measurements are reported in the literature to be essential for the containment of bacterial resistance with respect to the proper management of antimicrobials ${ }^{(9,13)}$.

Thus, the choice of empirical treatment should be based on the time of onset of infection, previous use of antibiotics, prolonged use of invasive procedures, the patient's advanced age (over 65), previous hospitalizations, presence of colonization and especially knowledge of the prevalence of microbial agents frequently in the institution ${ }^{(11,12,15,16)}$.

Studies show a low rate of prescribing appropriate empiric therapy, ranging between $26 \%$ and $51.8 \%$, with respect to dose, duration and antimicrobial indication $^{(15,17)}$. Thus, it is emphasized the importance of adjusting the ATB according to the results to be achieved as quickly as possible, even in order to reduce the emergence of bacterial resistance and hence in costs of antimicrobial treatment of patients ${ }^{(15)}$. In addition, an institutional culture to retarget the therapy may favor the prescription revision of the patients, reducing the possible mistakes made initially.

The choice of ATB to be used after microbiological confirmation should be performed evaluating five basic principles, such as: efficacy, safety, ease of administration, cost of ATB selected and, above all, the action spectrum, which should be as low possible, thus emphasizing the importance of antimicrobial de-escalation as essential in containing bacterial resistance ${ }^{(16)}$.

Regarding the most used ATB in targeted treatment of patients with bloodstream infection, confirming the results found in this research, is reported in the literature that vancomycin and oxacillin are the antimicrobial agents commonly used for gram-positive bacteria such as Staphylococcus aureus ${ }^{(17-20)}$.

Oxacillin or methicillin are narrow spectrum antimicrobials, belonging to the group of semisynthetic penicillin resistant to beta-lactamase and penicillinase staphylococci. They are indicated for the treatment of infections in various topographies caused by aerobic gram-positive microorganisms, among them, Staphylococcus aureus ${ }^{(19)}$. However, the resistance of such microorganisms to this drug is known and their usefulness is restricted for empiric therapy, and should only be used after culture results, with recognition of sensitive pathogens to this agent ${ }^{(10)}$.

Consequently, the use of vancomycin for empiric treatment in the institution studied is explained by the high prevalence of oxacillin resistant Staphylococcus aureus ${ }^{(21,22)}$. Vancomycin is a glycopeptide that acts on the inhibition of cell wall synthesis, having activity primarily on gram-positive bacteria, which sustain its wide use for the treatment of such microorganisms ${ }^{(19)}$. Conversely, it presents significant nephrotoxicity, especially in patients treated with doses greater than $4 \mathrm{~g} /$ day for more than 10 days. Therefore, it is recommended to monitor plasma levels of vancomycin and its administration to a continuous perfusion system, rather than multiple doses ${ }^{(10-11)}$.

Nevertheless, the study highlights the emergence of strains of Staphylococcus aureus with interme- 
diate resistance to vancomycin ${ }^{(20)}$. Thus, the use of such ATB for treating infection by Staphylococcus aureus must be prudent and must be alert to the need for additional therapeutic options, which justifies the recent studies testing new antibiotics as alternative therapy to vancomycin. Among these drugs, there is linezolid, which is an antimicrobial agent from the class of oxazolidinones recently developed (2001), which has bacteriostatic action against gram-positive microorganisms, including Staphylococcus aureus and Enterococcus spp ${ }^{(23,24)}$.

Researches comparing the effectiveness of linezolid in relation to vancomycin observed that, although the first is more expensive, the extra cost can be considered neutral due to the benefits of treatment with this ATB. The main advantages of linezolid are oral form availability, few cases of resistant strains reported so far, reduced side effects, the most common is thrombocytopenia, which is reversible by discontinuing the use of this agent. These characteristics results in an increased safety for patients ${ }^{(23-24)}$.

In relation to treatment costs, the observed de-escalation favored cost containment, reducing it statistically, after culture results $(p=0.000)$. It is noteworthy that we found no studies specifically evaluating costs on antimicrobial treatment of MRSA compared to MSSA bloodstream infections. However, a 2006 study evaluating various species of microorganisms, reported that de-escalation acted adjusting the antimicrobial treatment of patients in $88 \%$ of cases, reducing the action spectrum at $80 \%$, the number of prescribed antibiotics in $22 \%$ and the costs of antimicrobial treatment by $23 \%{ }^{(15)}$.

As a result, we highlight the importance of de-escalation not only in the containment of bacterial resistance, but favoring a reassessment of the prescription of the patients, reducing possible misunderstandings such as: indication, dosage and inadequate time, reduction in antimicrobial spectrum used and treatment costs.

When analyzing the cost of antimicrobials in an institution, especially in the ICU, it represents 30\% to $50 \%$ of total drug costs, and at least $50 \%$ of patients make use of some antibiotics on hospitalization, this study opens up spaces for reflection on institutions, especially the HICC and auditors to review the protocols used. These, if inadequate, may lead to an increase of antibiotics cost, especially when certain principles are not considered such as microbiological profile of the institution, possibility of de-escalation and time required for therapy.

Thus, it is suggested that further research on costs still evaluates the antimicrobial therapy adequacy, since variables such as antibiotics prescribed, dosage and length of the treatment used may influence the cost of patient care. In this regard, prospective studies can provide closer answers to reality, as the rigor of this type of follow-up presupposes the best compatibility of data, real-time analysis with different types of records, such as: medical prescription, nursing and pharmacy records, analysis of everyday situations, such as drug unavailability, drug suspension or patient's condition alteration, besides favoring possible adjustments, both as data and records in real time.

\section{CONCLUSION}

The most used antibiotics for empiric treatment of patients were broad-spectrum, such as: vancomycin, polymyxin, ertapenem and meropenem, justified by the microbiological profile of the institution and patient severity. In targeted treatment for patients with MRSA, vancomycin was the drug of first choice, and for patients with MSSA, oxacillin was the most used drug, in accordance with the main international and national guidelines.

It was found that the antimicrobial de-escalation, after the result of cultures, necessary for the containment of bacterial resistance, favored retargeting patient therapy, reducing, where necessary, the antimicrobial spectrum of action prescribed and, consequently, antimicrobial costs significantly $(p=0.01)$ for both patient groups (MSSA and MRSA).

Thus, the importance of encouraging the de-escalation performance whenever possible is emphasized, by concern over the emergence of resistant microorganisms, but also because it is a strategy of cost reduction with antimicrobial treatment.

In this regard, we emphasize the significance of this approach in relation to nursing actions, since as a member of the multidisciplinary team and in the approach of bacterial resistance, it is not the nurse responsibility to prescribe or de-escalation of antimicrobials, but knowing its implication for reducing costs to the institution, the impact of lower rates of morbidity and mortality in the context of this multifactorial event. 


\section{REFERENCES}

1. Decker MD, Schaffner W. Changing trends in infection control and hospital epidemiology. Infect Dis Clin North Am. 1989; 3(4):671-82.

2. Tavares W. [Problem gram-positive bacteria: resistance in staphylococci, enterococci, and pneumococci to antimicrobail drugs]. Rev Soc Bras Med Trop. 2000; 33(3): 281-301. Portuguese.

3. Balkhair A, Muharrmi Z, Darwish L, Farhan H, Sallam M. Treatment of vancomycin-intermediate Staphylococcus aureus (VISA) endocarditis with linezolid. Int J Infect Dis. 2010; 14 Suppl 3: e227-9.

4. Gregory CJ, Llata E, Stine N, Gould C, Santiago LM, Vazquez GJ, et al. Outbreak of carbapenem-resistant Klebsiella pneumoniae in Puerto Rico associated with a novel carbapenemase variant. Infect Control Hosp Epidemiol. 2010, 31(5):476-84.

5. Brasil. Ministério da Saúde. Agência Nacional de Vigilância Sanitária. Resolução n. 44, de 26 de outubro de 2010. Dispõe sobre o controle de medicamentos à base de substâncias classificadas como antimicrobianos, de uso sob prescrição médica, isoladas ou em associação e dá outras providências. Diário Oficial da República Federativa do Brasil; Brasília(DF); 2010 Out 28; Seção 1:76-77.

6. Ferrareze MV, Leopoldo VC, Andrade D, Silva MF, Haas VJ. [Multi-resistant pseudomonas aeruginosa among patients from an intensive care unit: persistent challenge?] Acta Paul Enferm [Internet]. 2007 [cited 2011 Dec 12]; 20(1):7-11. Portuguese. Available from: http:/ /www.scielo.br/pdf/ape/ v20n1/a02v20n1.pdf

7. Ritchie DJ, Alexander BT, Finnegan PM. New antimicrobial agents for use in the intensive care unit. Infect Dis Clin North Am. 2009; 23(3):665-81.

8. American Thoracic Society; Infectious Diseases Society of America. Guidelines for the management of adults with hospital-acquired, ventilator-associated, and healthcareassociated pneumonia. Am J Respir Crit Care Med. 2005; 171(4): 388-416.

9. Marra AR, Almeida SM, Correa L, Silva M Jr, Martino MD, Silva CV, et al. The effect of limiting antimicrobial therapy duration on antimicrobial resistance in the critical care setting. Am J Infect Control. 2009; 37(3): 204-9.

10. Olaechea Astigarraga PM, Garnacho Montero J, Grau Cerrato S, Rodríguez Colomo O, Palomar Martínez M, Zagoza Crespo R, et al. [GEIPC-SEIMC and GTEISEMICYUC recommendations for antibiotic treatment of gram positive coccal infections in the critical patient]. Med Intensiva. 2007; 31(6): 294-317. Spanish.

11. Mensa J, Barberán J, Llinares P, Picazo J, Bouza E, AlvarezLerma F, et al. [Guidelines for the treatment on infections caused by methicillin-resistant Staphylococcus aureus]. Rev Esp Quimioter. 2008; 21(4): 234-58. Spanish.

12. Sociedade Brasileira de Pneumologia e Tisiologia. Diretrizes brasileiras para o tratamento das pneumonias adquiridas no hospital e das associadas à ventilação mecánica. J Bras Pneumol. 2007; 33(Supl 1): S1-30.
13. Fishman N. Antimicrobial stewardship. Am J Med. 2006; 119(6 Suppl 1): S53-S61.

14. Board Governors of the Federal Reserve System. Foreign exchange rates - G.5 $5^{\text {a }}$ Internet]. 2011 [cited 2012 Set 10]. Available from: http://www.federalreserve.gov/releases/ g5a/20102006.htm

15. Berild D, Mohseni A, Diep LM, Jensenius M, Ringertz SH. Adjustment of antibiotic treatment according to the results of blood cultures leads to decreased antibiotic use and costs. J Antimicrob Chemother. 2006; 57(2): 326-30.

16. Cisneros-Herreros JM, Cobo-Reinoso J, Pujol-Rojo M, Rodríguez-Baño J, Salavert-Lletí M. Guía para el diagnóstico y tratamiento del paciente con bacteriemia. Guías de la Sociedad Española de Enfermedades Infecciosas y Microbiología Clínica (SEIMC). Enferm Infecc Microbiol Clín. 2007; 25(2):111-30.

17. Herzke CA, Chen LF, Anderson DJ, Choi Y, Sexton DJ, Kaye KS. Empirical antimicrobial therapy for bloodstream infection due to methicillin-resistant Staphylococcus aureus: no better than a coin toss. Infect Control Hosp Epidemiol. 2009; 30(11):1057-61.

18. Engemann JJ, Friedman JY, Reed SD, Griffiths RI, Szczech LA, Kaye KS, et al. Clinical outcomes and costs due to Staphylococcus aureus bacteremia among patients receiving long-term hemodialysis. Infect Control Hosp Epidemiol. 2005; 26(6):534-9.

19. Clinical and Laboratory Standards Institute. Performance standards for antimicrobial disk susceptibility tests; Approved standard - Tenth edition. Wayne (PA): Clinical and Laboratory Standards Institute; 2009. (CLSI document M02-A10)

20. Rehm SJ, Tice A. Staphylococcus aureus: methicillinsusceptible $\mathrm{S}$. aureus to methicillin-resistant $\mathrm{S}$. aureus and vancomycin-resistant S. aureus. Clin Infect Dis. 2010; 51 Suppl 2: S176-82.

21. Gudiol F, Aguado JM, Pascual A, Pujol M, Almirante B, Miró JM, et al. Documento de consenso sobre el tratamiento de la bacteriemia y la endocarditis causada por Staphylococcus aureus resistente a la meticilina. Enferm infecc Microbiol Clín. 2009; 27(2): 105-15.

22. Mermel LA, Allon M, Bouza E, Craven DE, Flynn P, O'Grady NP, et al. Clinical practice guidelines for the diagnosis and management of intravascular catheter-related infection: 2009 Update by the Infectious Diseases Society of America. Clin Infect Dis. 2009; 49(1):1-45.

23. Sirvent JM, Piñeiro L, de la Torre M, Motjé M, Batlle J, Bonet A. Linezolid more efficacious than vancomycin to eradicate infecting organism in critically ill patients with Gram-positive infections. Rev Esp Quimioter. 2010; 23(1): 27-35.

24. Gaite FB, Saénz AJ, Vidal MV, Perelló DC. Nuevas opciones terapêuticas para el tratamento de las bactérias multirresistentes en Unidades de Cuidados Intensivos. Rev Esp Quimioter. 2008; 21(1): 9-13. 